\title{
Performance of Anaerobic Germination-tolerant Rice Varieties in Direct Seeding: Effects on Stand Establishment, Weed Growth and Yield under Different Seeding Rates
}

\author{
T. K. Illangakoon ${ }^{*}$, B. Marambe ${ }^{1}$, R.S.K. Keerthisena ${ }^{2}$, A.P. Bentota ${ }^{2}$, S. Kulatunge ${ }^{2}$ \\ V. Kumar ${ }^{3}$ and A. Ismail ${ }^{3}$ \\ Postgraduate Institute of Agriculture \\ University of Peradeniya \\ Sri Lanka
}

\begin{abstract}
Weeds are the most disastrous constraint in direct-seeded rice (DSR). Anaerobic germination-tolerance (AG-tolerance), which is the ability of rice to germinate, grow and survive under oxygen-limited conditions, together with suitable management options is a better alternative to suppress weeds in DSR. This study was designed to identify the effect of seeding rate and AG-tolerant varieties on stand establishment, weed growth and yield of rice (Oryza sativa L.) germinated under submerged condition. The experiments were conducted in a split-split plot design with three replicates during the Maha season (October 2014 to February 2015) and the Yala season (March to September 2015). The two main plots consisted of different water levels; submerged (sowing into $5 \mathrm{~cm}$ of standing water) and saturated as in conventional DSR. Three seeding rates (100, 80 and $60 \mathrm{~kg} / \mathrm{ha})$ were allocated to sub-plots and three rice varieties viz. Ciherang AG1+Subl and IR64+AG1 (two standard AG-tolerant rice varieties from the International Rice Research Institute (IRRI) at The Philippines), and Bg366 (from Sri Lanka) were allocated to sub-sub plots. Submergence reduced the stand establishment, panicle density and yield in all varieties compared to the saturated condition $(P<0.05)$. It also reduced the total weed density by more than 5 -fold, and biomass of grasses and sedges by $96 \%(P<0.05)$, however, there was no effect $(P>0.05)$ on aquatic and semi-aquatic weeds. The highest seedling and panicle densities, and yield under submerged conditions were recorded with the seeding rate of $100 \mathrm{~kg} / \mathrm{ha}$. Under the submergence, the rice variety Bg366 showed the lowest stand establishment and panicle density, however, recorded a comparable yield to that of Ciherang AGI+SUBI and a higher yield than IR64+AG1. The results highlighted the need of novel AG-varieties, screening Sri Lankan rice varieties for AG-tolerance and finding suitable management options capable of producing high stand establishment and yield from DSR under submerged condition.
\end{abstract}

Keywords: Anaerobic germination-tolerance, direct seeded rice, management options

\section{INTRODUCTION}

About $95 \%$ of the rice (Oryza sativa L.) grown in Sri Lanka is direct-seeded. Apart from irregular stand establishment, the most disastrous constraint in direct-seeded rice (DSR)

\footnotetext{
1 Department of Crop Science, Faculty of Agriculture, University of Peradeniya, Sri Lanka

Rice Research and Development Institute, Bathalagoda, Ibbagamuwa, Sri Lanka

3 International Rice Research Institute, Los Banos, Philippines

* Corresponding author: thanuja1234@yahoo.com
} 
across all rice growing agro-ecologies is the invasion of weeds (Gunawardhana et al., 2013). The relative yield loss caused by uncontrolled weeds has been reported to be as high as 80 $90 \%$ in dry-DSR (Sunil et al., 2010; Chauhan and Johnson, 2011) whereas in Sri Lanka, it has ranged from 20-40\% (Amarasinghe et al., 1999; Herath Banda et al., 1998).

Farmers generally use herbicides to control weeds however, their excessive and indiscriminate use have created many environmental problems in the global scale. Increasing seeding rate also suppresses weed growth to a certain extent. In a weedy situation, the maximum grain yield that could be achieved from increasing the seeding rate vary from 95 to $125 \mathrm{~kg} \mathrm{seed} / \mathrm{ha}$ (Chauhan and Yadev, 2013). However, increasing seeding rates in DSR systems under weed-free situation have had no significant impact on the grain yield of rice (Chauhan et al., 2013). In Sri Lanka, seeding rate of 75-100 kg/ha has been recommended for direct wet-seeded rice (wet DSR) however, seed rate used by farmers varies from 70 to $220 \mathrm{~kg} / \mathrm{ha}$ (Kumar and Ladha, 2011). Farmers who practice Kekulan cultivation (dry seeding) also use a higher seeding rate of $250-350 \mathrm{~kg} / \mathrm{ha}$ with the perception of suppressing weeds.

Water management aiming at weed control in rice has long been practiced in lowland transplanted rice (Rao et al., 2007). Juraimi et al. (2012) reported that flooding up to $5.1 \mathrm{~cm}$ effectively reduces the germination of Echinochloa colona (L.) Link., with 35\% germination of rice seeds. Emergence of E. crus-galli (L.) Beauv., E. colona, Cyprus iria (L.) and Rhynchospora corymbosa (L.) Britton was also lower in soils flooded up to $4 \mathrm{~cm}$ water depth compared to seeds sown in saturated soils (Ismail et al., 1996). Estioko et al. (2014) observed that early flooding (10 cm of water) immediately after seeding was more effective in suppressing the growth of E. crus-galli. However, in DSR systems, fields are drained before sowing, and impounding standing water is delayed usually by 7-10 days until rice seedlings have emerged, as many cultivated rice varieties are highly sensitive to flooding during germination (Ismail et al., 2012). This practice results in higher emergence of weed seeds in DSR systems.

Among the thousands of rice cultivars studied, some have shown the ability to germinate and elongate coleoptiles under low $\mathrm{O}_{2}$ (hypoxia) or very low/absence of $\mathrm{O}_{2}$ (anoxia). The ability of rice to germinate, grow and survive under oxygen-limited conditions is known as anaerobic-germination tolerance (AG-tolerance; Ella and Setter, 1999). Such cultivars help reducing the hazards of early floods and provide an efficient means for weed control in DSR (Ismail et al., 2012). Five QTLs responsible for AG-tolerance in rice have been identified and the largest QTL (referred to as AG1) derived from the variety Khao Hlan On has been mapped, which explains $18-34 \%$ of the phenotypic variability (Ismail et al., 2009). It was further fine-mapped and cloned to facilitate their use in breeding (Angaji et al., 2010). The AG-tolerant rice cultivars develop different strategies to cope up with $\mathrm{O}_{2}$-limited conditions, including anaerobic respiration to sustain energy supply, initiation and maintenance of carbohydrate catabolism in germinating seeds, and maintenance of cellular extensibility of the growing embryo (Ismail et al., 2009). They also store relatively more soluble sugars in the endosperm than that of sensitive genotypes, and have greater ability to break down starch into soluble sugars during germination due to higher activity of $\alpha$-amylases.

The AG-tolerant varieties together with water seeding (a technology of sowing of dry or soaked seed into flooded field) and season-long submergence may be a good alternative to herbicides to suppress weeds in DSR. However, no attempt has been made in Sri Lanka to evaluate the effectiveness of AG-tolerant varieties and their management for controlling weeds in DSR. Therefore, this study attempted to assess the performance of two standard 
AG-tolerant rice varieties with a popular Sri Lankan variety for stand establishment, weed growth and yield under different seeding rates and water levels at time of sowing.

\section{MATERIALS AND METHODS}

Experiments were conducted at the Rice Research and Development Institute (RRDI) of the Department of Agriculture (DOA) located in Ibbagamuwa ( $\mathrm{IL}_{1 \mathrm{~b}}$, North Western Province), Sri Lanka during the Maha season (October 2014 - February 2015) and Yala season (March September, 2015). The experimental fields were ploughed twice, puddle and leveled at two days prior to seed sowing. The experiments were conducted in a split-split plot design with three replicates. The main plots were assigned to two water levels as submerged (sowing into $5 \mathrm{~cm}$ of standing water, which was maintained up to 21 days and then the field was maintained under continuous irrigation with 3-4 $\mathrm{cm}$ of water until mid-maturity) and saturated (sowing under saturated condition and irrigated with 3-4 cm of water after 10 days as in wet DSR and maintained until mid-maturity). The sub plots and sub-sub plots were assigned to seeding rates and varieties, respectively. Two AG-tolerant gene-incorporated varieties viz., Ciherang AG 1+Sub 1 and IR 64+AG 1 imported from the International Rice Research Institute (IRRI) in the Philippines were tested with Bg366 from Sri Lanka which is one of the popular high yielding variety using three seeding rates $(100,80$ and $60 \mathrm{~kg} / \mathrm{ha})$. All three varieties belonged to the 3.5 months age class.

Pre-germinated seeds (soaked in water for $24 \mathrm{~h}$ and incubated for $48 \mathrm{~h},>85 \%$ germination) were broadcasted into plots at a size of $3 \mathrm{~m} \mathrm{x} 3 \mathrm{~m}$. Fertilizer application was done as 55 $\mathrm{kg} / \mathrm{ha}$ of Triple Super Phosphate (basal dressing), $225 \mathrm{~kg} / \mathrm{ha}$ of Urea (split application at 3,5, 7, and 8 weeks) and $60 \mathrm{~kg} / \mathrm{ha}$ of Muriate of Potash (split application at 5 and 7 weeks) as recommended by the Department of Agriculture (DOA, 2013) for the irrigated rice cultivation in the Dry and Intermediate zones using rice varieties of 3.5 months age class. The number of rice seedlings and weeds $/ \mathrm{m}^{2}$ were recorded 3 and 4 weeks after sowing (WAS) using a quadrant $(0.5 \mathrm{~m} \times 0.5 \mathrm{~m})$ placed randomly in each sub-sub plots twice. Weeds in an area of $0.25 \mathrm{~m}^{2}$ in each sub-sub plot were uprooted at 6 WAS, separated into different categories as grasses, sedges and broad leaves, dried in shade, oven-dried at $50{ }^{\circ} \mathrm{C}$ for 7 days, and dry weights were taken. Thereafter, the plots were hand-weeded and kept weed-free until harvesting. The panicle number $/ \mathrm{m}^{2}$ was taken at the end of maturity stage by using a randomly placed quadrant. The grain yield was harvested from $7.3 \mathrm{~m}^{2}$ area in each sub plot at $85 \%$ physiological maturity.

\section{Statistical analysis}

Data were statistically analyzed using the SAS statistical software (9.1). Variations in tiller and panicle number, and weed densities were analyzed using categorical data analysis. Analysis of Variance (ANOVA) was performed for weed weight and crop yield. Mean separation was done using the Least Significant Difference (LSD) at $P=0.05$. 


\section{RESULTS AND DISCUSSION}

\section{Variation in stand establishment and panicle density}

The water level at sowing affected the stand establishment $(P<0.001)$, which was expressed as seedling density, both in the Maha 2014/2015 and in the Yala season 2016. The stand establishment of rice crop was reduced by $19 \%$ under submergence compared to that of saturated condition (Figure 1). Ella et al. (2010) reported that the survival rate of rice plants decreases under limiting $\mathrm{O}_{2}$ and light transmission under water, but to a lesser extent in AGtolerant genotypes. The higher seedling survival and alpha-amylase activity in intermediate water temperatures $\left(24-26^{\circ} \mathrm{C}\right)$, which decreased in cooler $\left(18-20{ }^{\circ} \mathrm{C}\right)$ water temperatures as revealed by Ella et al. (2010) suggest that an optimum threshold temperature is needed for seed germination and seedling survival of rice plants under flooded conditions. Similarly, the panicle density of rice in this study was significantly reduced by $14.8 \%$ under submerged condition $(P<0.001)$ compared to that in saturated condition (Figure 1). In DSR, the panicle numbers around $300 / \mathrm{m}^{2}$ is considered to be the optimum for the maximum productivity (Shaobing et al., 2008). Therefore, the use of higher seeding rates or decreasing water depth $(<5 \mathrm{~cm})$ would increase the stand establishment and panicle density of rice sown under submerged condition.

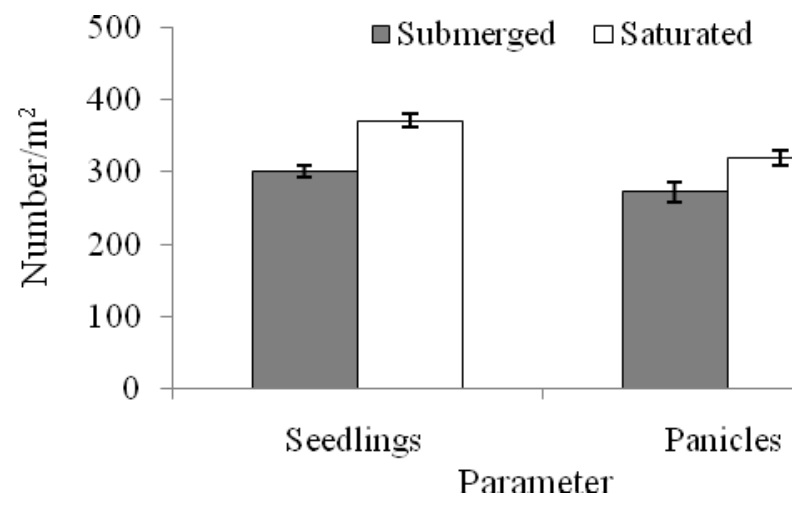

Figure 1. Seedling and panicle densities at submerged $(5 \mathrm{~cm}$ water height) and saturated conditions.

Data presented are the average of the Maha 2014/2015 and the Yala 2015 seasons. Vertical lines indicate means \pm standard error.

Stand establishment also varied significantly at different seeding rates $(P<0.01)$ under submerged and saturated conditions in both seasons. The stand establishment recorded in the plots with a seeding rate of $100 \mathrm{~kg} / \mathrm{ha}$ was $13.3 \%$ and $14.8 \%$ higher compared to that at 60 $\mathrm{kg} / \mathrm{ha}$ under submerged and saturated conditions, respectively (Figure 2). A significant variation in panicle density $(P<0.01)$ with seeding rate was only observed under submerged condition. 

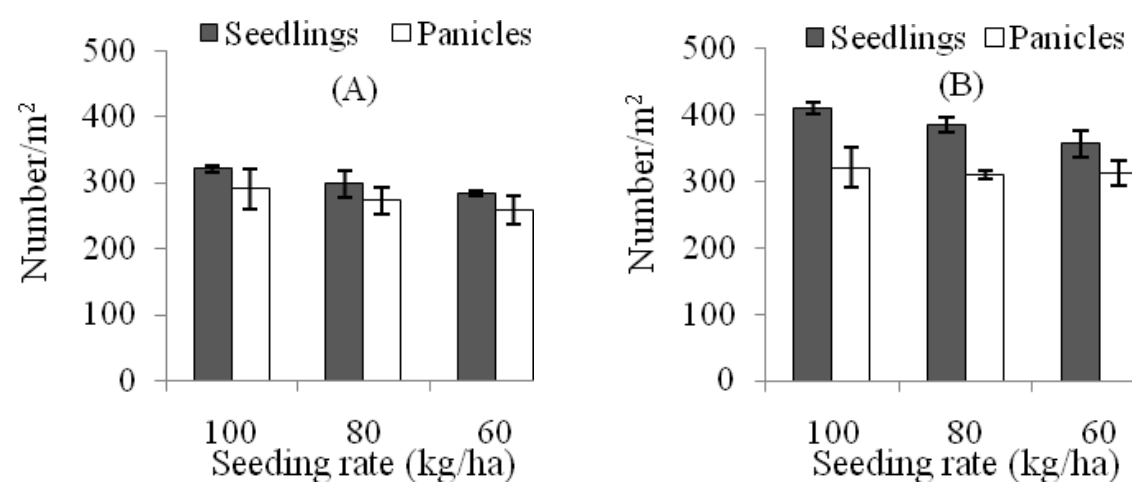

Figure 2. Seedling and panicle densities under (A) submerged (5 $\mathrm{cm}$ water depth) and (B) saturated condition at different seeding rates.

Data presented are the average of the Maha 2014/2015 and the Yala 2015 seasons. Vertical lines indicate mean \pm standard error.

A significant interaction $(P<0.05)$ between water level and seeding rate was observed in the Maha season 2014/2015. The panicle density increased with increasing seeding rate under submerged condition, but showed similar values under saturated conditions at $60 \mathrm{~kg} / \mathrm{ha}$ and $80 \mathrm{~kg} / \mathrm{ha}$.

The stand establishment and panicle density of the three varieties varied significantly $(P<0.05)$ under both submerged and saturated condition (Figure 3). A significant interaction between water level and variety $(P<0.01)$ was also recorded. Ciherang AG1+SUB1 and IR 64+AG 1 recorded more than 350 seedlings $/ \mathrm{m}^{2}$ while $\mathrm{Bg} 366$ recorded around 320 seedlings $/ \mathrm{m}^{2}$ under submerged conditions. Thus, the stand establishment recorded by AGincorporated varieties under submerged conditions was approximately 15-18\% higher compared to that of the Sri Lankan check variety. Although, the QTLs of AG was reported to contribute $18-34 \%$ of phenotypic variation under submerged condition, the results of the present study showed a comparatively lower increase in the stand establishment of AGtolerant rice varieties in compared to that of the Sri Lankan variety under field conditions at Batalagoda. However, all varieties produced above 360 seedlings $/ \mathrm{m}^{2}$ under saturated conditions (Figure 3). Though Bg 366 had the lowest stand establishment under submerged condition, it had comparatively higher establishment under saturated condition. In contrast, IR 64+AG1, which had the highest stand establishment under submerged condition, recorded the lowest under saturated condition. 


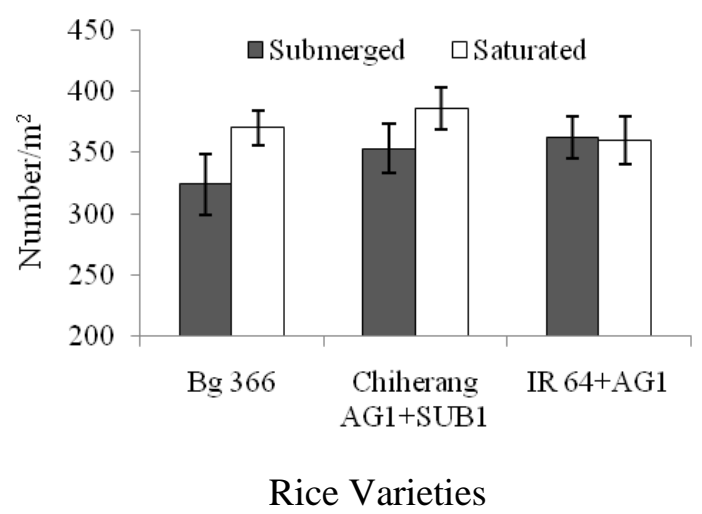

Figure 3. Seedling densities of test varieties under submerged and saturated conditions. Data presented are the average of Maha 2014/2015 and Yala 2015 seasons. Vertical lines indicates mean \pm standard error

The panicle density among varieties varied only in the Yala season 2015 (Figure 4). Similar to the results of the stand establishment, the highest panicle density among varieties under submerged condition was recorded in IR $64+\mathrm{AG} 1\left(309 / \mathrm{m}^{2}\right)$ while the lowest was in Bg366 (27.4\% low). However, all varieties produced panicle densities over $300 / \mathrm{m}^{2}$ under saturated condition $(P>0.05)$.

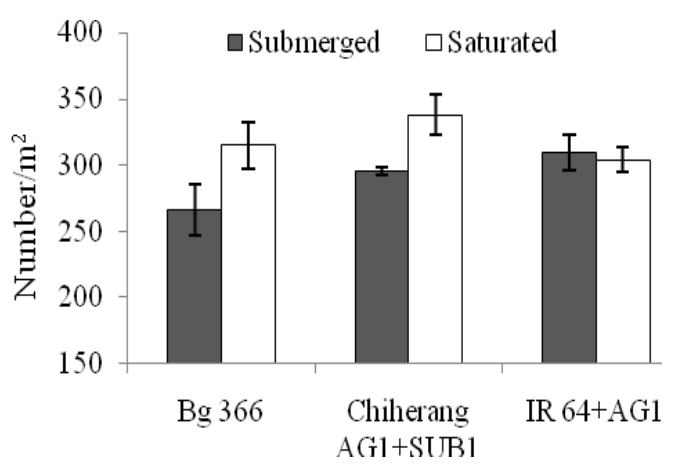

Rice Varieties

Figure 4. Panicle densities of different varieties in the Yala season 2015. Vertical lines indicate mean \pm standard error

No significant interaction effects were recorded $(P>0.05)$ in both seasons between the seeding rate and variety or among water level, seeding rate and variety for stand establishment and panicle density.

\section{Variation in weed growth}

The water level at time of sowing and the seeding rate affected the weed density $(P<0.01$ and $P<0.05$, respectively) but the variety had no significant impact $(P>0.05)$. The interaction effect between water level and seeding rate was also found to be statistically significant $(P<0.05)$. Seeding with submergence having $5 \mathrm{~cm}$ of standing water drastically reduced the 
weed emergence (Figure 5). The average weed density under submergence $\left(57 / \mathrm{m}^{2}\right)$ was only $18.6 \%$ of that under saturated conditions $\left(302 / \mathrm{m}^{2}\right)$. The weed density increased with decreasing seeding rate under saturated condition, however, such relationship was not observed under submerged condition indicating that the seeding rate had no effect in suppressing the weed growth under submerged condition. Ella et al. (2010) reported that the shallow water depths tend to increase weed growth while water depths of $5 \mathrm{~cm}$ coupled with healthy seeds of AG-tolerant genotypes can probably suppress the growth of most weeds without much reduction in seedling survival and establishment of the rice crop. Begum et al. (2006) also reported that flooding at a depth up to $5 \mathrm{~cm}$ at time of sowing maintaining water levels for at least 14 days is effective in controlling the emergence and growth of the annual sedge Fimbristylis miliacea (L.) Vahl. The present study also highlighted the importance of submergence as an alternative strategy for herbicides in weed management in DSR.

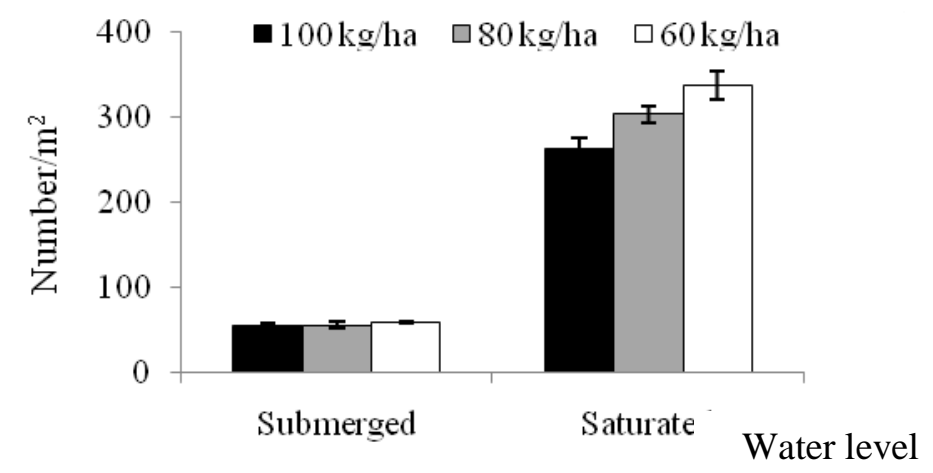

Figure 5. Weed density under submerged $(5 \mathrm{~cm})$ and saturated conditions in different seeding rates.

Data presented are the average of the Maha 2014/2015 and the Yala 2015 seasons. Vertical lines indicate mean \pm standard error.

Among the weeds recorded under submerged condition, $87 \%$ were broad leaves while the majority of the weeds reported in saturated water level were grasses (81\%; Figure 6). The number of sedges was the lowest in both submerged and saturated condition. The main grass species found under saturated condition was E. crus-galli, which is one of the problematic grasses found in paddy fields in Sri Lanka (Marambe et al., 2015). Ismail et al. (1996) reported that $5 \mathrm{~cm}$ submergence level at time of sowing could drastically reduce the grasses, including E. crus-galli, and sedges compared to that under saturated condition. The present study also provided further scientific evidence for the effectiveness of submergence in controlling E. crus-galli. Monochoria vaginalis (Brum.f.) Presl. and Marsilea quadrifolia L., which are semi-aquatic and aquatic broadleaves, respectively, were the dominant broadleaves under submerged condition.

Figure 6. Weed composition under (A) submerged and (B) saturated water levels. Data are presented as the average of the Maha 2014/2015 and the Yala 2015 seasons.

The weed biomass recorded under submergence $\left(47.8 \mathrm{~g} / \mathrm{m}^{2}\right)$ was only $57.7 \%$ of that recorded under saturated condition indicating that submergence has suppressed the weed biomass (Table 1). Among the weeds present in DSR in Sri Lanka, grasses are the most troublesome species responsible for grain yield reduction. These results highlighted the importance of submergence at $5 \mathrm{~cm}$ standing water at time of seeding in suppressing the 
biomass of grasses and sedges by $96 \%$ under submergence compared to that under saturated condition. However, submerged condition did increase the aquatic broad leaves by $80 \%$ where the biomass of broad leaves was significantly higher $(P<0.05)$ than sedges and grasses. Therefore, any alternative weed control measure should be adopted depending on the presence of aquatic weeds.

Table 1. Dry weights of different weed categories under standing water and saturated conditions

\begin{tabular}{|c|c|c|}
\hline \multirow[b]{2}{*}{ Weed category } & \multicolumn{2}{|c|}{ Weed biomass $\left(\mathrm{g} / \mathrm{m}^{2}\right)$} \\
\hline & $\begin{array}{c}\text { Submerged } \\
(5 \mathrm{~cm} \text { Standing water })\end{array}$ & Saturated condition \\
\hline Broad leaves & $44.9^{\mathrm{a}}$ & $11.4^{\mathrm{b}}$ \\
\hline Grasses & $2.7^{\mathrm{b}}$ & $66.8^{\mathrm{a}}$ \\
\hline Sedges & $0.2^{\mathrm{b}}$ & $4.6^{\mathrm{b}}$ \\
\hline Total biomass & 47.8 & 82.8 \\
\hline $\mathrm{CV} \%$ & 22.9 & 12.2 \\
\hline
\end{tabular}

Note: Within a column, means with same superscripts are not significantly different by the LSD at $P=0.05$. Data presented are the average of the Maha 2014/2015 and Yala 2015 seasons.

\section{Variation in grain yield}

Grain yield varied significantly with the water level $(P<0.01)$, seeding rate $(P<0.05)$ and variety $(P<0.01)$ in both seasons. The interactions between the water level $x$ seeding rate as well as seeding rate $x$ variety also influenced the yield in the Maha season 2014/2015 $(P<0.01$ and $P<0.05$, respectively)

Grain yields reduced significantly under submerged condition $(P<0.05)$ by about $30-32 \%$ compared to that of the saturated condition (Table 2). The low yield under submergence could be attributed to the lower stand establishment and panicle density compared to those under saturated condition. This also emphasizes the need of increasing seeding rate, reducing water level and introducing better AG-tolerant varieties in order to use this technology

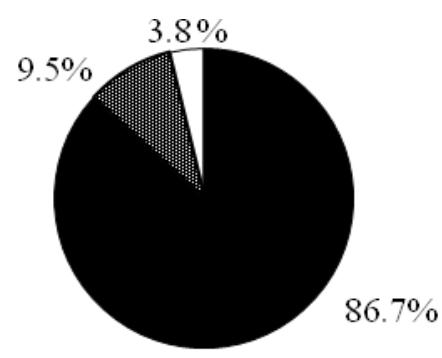

- Broad leaves $\quad$ Grasses $\square$ Sedges

(A)

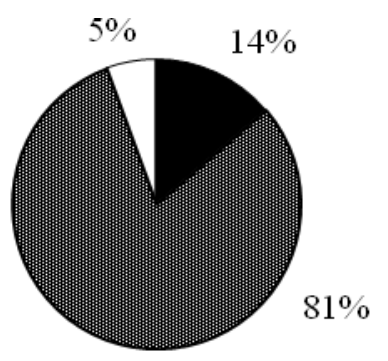

Broad leaves $\mathbf{n}$ Grasses $\square$ Sedges effectively under DSR.

(B) 
Table 2. Grain yield under submerged and saturated conditions

\begin{tabular}{lcc}
\hline \multirow{2}{*}{ Water level } & \multicolumn{2}{c}{ Mean yield (t/ha) } \\
\cline { 2 - 3 } & Maha $2014 / 2015$ & Yala 2015 \\
\hline Submerged & $3.2^{\mathrm{b}}$ & $2.3^{\mathrm{b}}$ \\
Saturated & $4.6^{\mathrm{a}}$ & $3.4^{\mathrm{a}}$ \\
CV \% & 15.3 & 17.9 \\
\hline Note: Within a column, means with same superscripts are not significantly different by the LSD at $P=0.05$
\end{tabular}

A significantly higher yield $(P<0.05)$ under submerged condition was recorded from plots seeded at a rate of $100 \mathrm{~kg} / \mathrm{ha}(3.7 \mathrm{t} / \mathrm{ha})$ followed by $80 \mathrm{~kg} / \mathrm{ha}(3.2 \mathrm{t} / \mathrm{ha})$ in the Maha season 2014/2015 while the lowest yield was recorded from those seeded at a rate of $60 \mathrm{~kg} / \mathrm{ha}$ (Table 3). However, the yields recorded in both 100 and $80 \mathrm{~kg} / \mathrm{ha}$ of seeding rates were similar in the Yala season 2015. This could be attributed to the better stand establishments and panicle densities at higher seeding rates under submerged condition compared to the lower seeding rates. Under saturated condition, seedling rates of $100 \mathrm{~kg} / \mathrm{ha}$ and $80 \mathrm{~kg} / \mathrm{ha}$ produced higher paddy grain yield $(P<0.05)$ in the Maha season 2014/2015. However, all the seeding rates recorded similar yields $(P>0.05)$ in the Yala season 2015 . These results tally with those of Chauhan et al. (2013) who reported that the seeding rates ranging from 15 to $125 \mathrm{~kg} / \mathrm{ha}$ had no impact on the grain yield of rice grown in weed-free conditions.

Table 3. Grain yields of different seeding rates under submerged and saturated water levels in the Maha season 2014/2015 and Yala season 2015

\begin{tabular}{lcccc}
\hline \multirow{2}{*}{$\begin{array}{c}\text { Seeding rate } \\
\text { (kg/ha) }\end{array}$} & \multicolumn{2}{c}{ Maha $2014 / 2015$} & \multicolumn{2}{c}{ Yala 2015 } \\
\cline { 2 - 5 } & Submerged & Saturated & Submerged & Saturated \\
\hline 100 & $3.7^{\mathrm{a}}$ & $4.9^{\mathrm{a}}$ & $2.8^{\mathrm{a}}$ & $3.6^{\mathrm{a}}$ \\
80 & $3.2^{\mathrm{b}}$ & $4.7^{\mathrm{ab}}$ & $2.3^{\mathrm{ab}}$ & $3.4^{\mathrm{a}}$ \\
60 & $2.5^{\mathrm{c}}$ & $4.2^{\mathrm{b}}$ & $1.7^{\mathrm{b}}$ & $3.1^{\mathrm{a}}$ \\
$\mathrm{CV} \%$ & 22.5 & 13.3 & 18.0 & 11.3 \\
\hline
\end{tabular}

Within a column, means with same superscript are not significantly different by the LSD at $p=0.05$

In the two seasons, the grain yield among the test varieties varied between seeding rates of 100 and $80 \mathrm{~kg} / \mathrm{ha}$ under submerged condition, but showed similar grain yields $(P>0.05)$ at 60 $\mathrm{kg} / \mathrm{ha}$ (Table 4). The varieties Bg366 and Cihernag AG1+SUB 1 produced higher yields $(P<0.05)$ compared to IR $64+$ AG1 in both seasons indicating their probable use under submerged condition. Further, this study did not show any significant yield advancement by the AG-incorporated standard varieties compared to that of the Sri Lankan variety Bg366, which has not been assessed for QTLs to-date. Thus, identification of better AG-varieties adapted to local rice growing eco-systems together with suitable management options are essential and should be further investigated. 
Table 4. Yields of different varieties with different seeding rates in the Maha season 2014/2015 and Yala season 2015 under submerged condition

\begin{tabular}{lcccccc}
\hline \multirow{2}{*}{ Variety } & \multicolumn{3}{c}{ Maha 2014/15 } & \multicolumn{3}{c}{ Yala 2015 } \\
\cline { 2 - 7 } & 100 & 80 & 60 & 100 & 80 & 60 \\
\hline Bg 366 & $4.5^{\mathrm{a}}$ & $4.0^{\mathrm{a}}$ & $2.8^{\mathrm{a}}$ & $3.6^{\mathrm{a}}$ & $2.9^{\mathrm{a}}$ & $1.7^{\mathrm{a}}$ \\
CiherangAG & $3.7^{\mathrm{a}}$ & $3.7^{\mathrm{a}}$ & $2.5^{\mathrm{a}}$ & $3.4^{\mathrm{a}}$ & $2.7^{\mathrm{a}}$ & $1.8^{\mathrm{a}}$ \\
1+Sub 1 & & & & & & \\
IR 64+AG 1 & $2.3^{\mathrm{b}}$ & $2.0^{\mathrm{b}}$ & $2.1^{\mathrm{a}}$ & $2.7^{\mathrm{b}}$ & $1.6^{\mathrm{b}}$ & $1.4^{\mathrm{a}}$ \\
CV\% & 17.1 & 26.5 & 28.6 & 20.5 & 20.1 & 30.2
\end{tabular}

Note: Within a column, means with same superscript are not significantly different by the LSD at P=0.05

Even though IR 64+AG1 produced the highest stand establishment and panicle density among the three varieties tested under submerged condition, it had significantly lower yield $(P<0.05)$ compared to $\mathrm{Bg} 366$ and Ciherang AG1+SUB1. In contrast, Bg 366, which had poor stand establishment and lower panicle density recorded the highest yield under submergence. Both high panicle weight $(4.0 \mathrm{~g} / \mathrm{panicle})$ and seed number /panicle (187) in $\mathrm{Bg} 366$ may have attributed to its higher yields compared to that of IR 64+AG1 under submergence (Table 5). Similarly, Cihernag AG1+SUB1 produced higher yield mainly owing to its 1000 grain weight $(27.5 \mathrm{~g})$, which was higher compared to that of IR 64+AG1. These results emphasize that the yield under submergence is greatly influenced by the inherent varietal characters despite their AG-tolerance ability.

Table 5. Panicle weight, seeds/panicle and weight of 1000 grains of test varieties under submerged condition (Maha 2014/2015)

\begin{tabular}{lccc}
\hline Variety & Panicle weight $(\mathrm{g})$ & $\begin{array}{c}\text { Number of } \\
\text { seeds/panicle }\end{array}$ & $\begin{array}{c}\text { Weight of } 1000 \\
\text { grains }(\mathrm{g})\end{array}$ \\
\hline Bg 366 & $4.0^{\mathrm{a}}$ & $187^{\mathrm{a}}$ & $23.6^{\mathrm{c}}$ \\
Cihernag & $2.7^{\mathrm{b}}$ & $106^{\mathrm{b}}$ & $27.5^{\mathrm{a}}$ \\
AG1+SUB1 & & & \\
IR 64+AG1 & $2.1^{\mathrm{c}}$ & $86^{\mathrm{c}}$ & $25.1^{\mathrm{b}}$ \\
CV\% & 11.3 & 14.7 & 3.2 \\
\hline
\end{tabular}

Note: Within a column, means with same superscript are not significantly different by the LSD at P=0.05.

\section{CONCLUSIONS}

Submergence with $5 \mathrm{~cm}$ standing water at the time of seeding in DSR reduced the stand establishment, panicle density and yield of rice plants, however, suppressed the weed density by more than 5 -fold, especially the biomass of grasses and sedges by $96 \%$, compared to those under saturated condition. The seeding rate of $100 \mathrm{~kg} / \mathrm{ha}$ gave the highest seedling establishment, panicle density and yield under submerged condition and therefore, considered as the best seeding rate among the treatments. The AG-incorporated standard varieties provided by the IRRI did not exhibit major yield advancements over Bg366 under submergence. This study highlights the need of novel AG-incorporated varieties that are adapted to local condition, and screening of locally available varieties for AG-tolerance, coupled with suitable management options for a satisfactory stand establishment, effective weed control and comparatively higher yields under submerged DSR compared to that under saturated condition. 


\section{ACKNOWLEDGEMENT}

Authors wish to acknowledge IPDSRA project DRPC 2013 from the International Rice Research Institute (IRRI), Los Banos, The Philippines for providing financial assistance and germplasm for this project.

\section{REFERENCES}

Amarasinghe, L., Marambe, B. and Rajapakse, R.P.A.D. (1999). Effect of quinclorac on weed control and productivity of wet-seeded rice in the mid country region of Sri Lanka. Sri Lankan J. Agric. Sci. 36, 24-34.

Angaji, S., Septiningsih, E., Mackill, M.D.J. and Ismail, A.M. (2010). QTLs associated with tolerance of anaerobic conditions during germination in rice (Oryza sativa L.). Euphytica. $172,159-168$.

Begum, M., Juraimi, A.S., Amartalingam, R., Man, A.B. and Rastans, S.O.B.S. (2006). The effects of sowing depth and flooding on the emergence, survival and growth of Fimbristylis miliacea (L.) Vahl. Weed Biol. Manag. 6, 57-167.

Chauhan, B.S., Abeysekara, A.S.K., Kulatunga, S.D. and Madusanka, I.U. (2013). Weed growth and grain yield, as affected by herbicides in dry-seeded rice in Sri Lanka. J. Crop Imp. 27, 41-429.

Chauhan, B.S. and Johnson, D.E. (2011). Row spacing and weed control timing affect yield of aerobic rice. Field Crops Res. 121, 226-231.

Chauhan, B.S. and Yadev, A. (2013). Weed management approaches for dry-seeded rice in India: a review. Indian J. Weed Sci. 45(1), 1-6.

Ella, E.S., Maribel, L.D.S. and Ismail, A.M. (2010). Management improves seedling survival and growth during early flooding in contrasting rice genotypes. Crop Sci. 50, 1021-1035.

Ella, E.S. and Setter, T.L. (1999). Importance of seed carbohydrates in rice seedling establishment under anoxia. Acta Horti. 504, 209-216.

Estioko, L.P., Miro, B., Baltazar, A.M., Merca, F.E., Ismail, A.M. and Johnson, D.E. (2014). Differences in responses to flooding by germinating seeds of two contrasting rice cultivars and two species of economically important grass weeds. AoB Plants, 6. doi: 10.1093/aobpla/plu064.

Gunawardhana, W.G.N., Ariyaratne, M., Bandaranayake, P. and Marambe, B. (2013). Control of Echinochloa colona in aerobic rice: Effect of different rates of seed paddy and post-plant herbicides in the dry zone of Sri Lanka. pp. 431-437. In: Bakar, B.B., Kurniadie, D. and Tjitrosoedirdjp, S. (Ed.). In proceeding at $24^{\text {th }}$ Asian-Pacific Weed Science Society, Bandung, Indonesia.

Herath Banda, R.M., Danapala, M.P., De Silva, G.C.A. and Hossain, M. (1998). Constraints to increase rice production in Sri Lanka. In Paper presented at the Workshop on Prioritization of Rice Research. International Rice Research Institute, Los Banos, Laguna, Philippines. 
Ismail, B.S., Rosmini, B.I. and Samiah, K. (1996). Factors affecting germination of Siam weed [Chromolaena odorata (L.) King and Robinson] seeds. Plant Prot. Quart. 11, 2-5.

Ismail A.M., Johnson, D.E., Ella, E.S., Vergara, G.V. and Baltazar, A.M. (2012). Adaptation to flooding during emergence and seedling growth in rice and weeds and implications for crop establishment. [online]. [Accessed on 14.07.2015]. Available at. http://www.aobplants.oxfordjournals.org

Ismail A.M., Ella, E.S., Vergara, G.V. and Mackill, D.J. (2009). Mechanisms associated with tolerance to flooding during germination and early seedling growth in rice (Oryza sativa). Ann. Bot. 103,197-209.

Juraimi, A.S., Ahmad-Hamdani, M.S., Anuar, A.R., Azmi, M., Anwar, M.P. and Kamal, U. M. (2012). Effect of water regimes on germination of weed seeds in Malaysian rice fields. Australian J. Crop Sc. 6(4), 598-605.

Kumar, V. and Ladha, J.K. (2011). Direct seeding of rice: Recent Development and future research need. Adv. Agron. 111, 331-333.

Marambe, B., Abeysekara A. and Herath, S. (2015). Weeds and weed management in agricultural and natural ecosystems: An overview of the Sri Lankan contest. pp. 213-240. In: Rao, V.S., Yaduraju, N.T., Chandrasena, N.R., Hanan, G. (Ed.) Weed Science in the AsiaPacific region, Hyderabad, India.

Rao, A.N., Johnson, D.E., Sivaprasad, B., Ladha J.K. and Mortimer, A.M. (2007). Weed management in direct seeded rice. Adv. Agron. 93, 153-255.

Shaobing, P.S.K., Gurdev, V., Palminder, T., Qiyuanand, T. and Yingbin, Z. (2008). Progress in ideotype breeding to increase rice yield potential. Field Crops Res. 108, 32-38.

Sunil, C.M., Shekara, B.G., Kalyanmurthy, K.N. and Shankaralingapa, B.C. (2010). Growth and yield of aerobic rice as influenced by integrated weed management practices. Indian $\mathrm{J}$. Weed Sci. 42(3\&4), 180-183. 